\title{
CRÔNICA E BRASILIDADE: A CATAÇÃO DO MÍNIMO E DO ESCONDIDO
}

\author{
Eduardo Luz \\ Universidade Federal do Ceará \\ Fortaleza (CE), Brasil
}

\begin{abstract}
Acho que posso ver os sinais precisos e distintivos das características nacionais mais nessas minutiae absurdas do que nas mais importantes questões de Estado; nos lugares em que os grandes de todas as nações falam e se pavoneiam de maneira tão semelhante, eu não daria nove tostões para escolher entre elas.
\end{abstract}

Laurence Sterne

Resumo: Entre 1892 e 1897, Machado de Assis escreveu as 246 crônicas de "A Semana". À época, já sofrera uma série de decepções: entre elas, não frutificara a cena brasileira nos moldes do teatro realista francês; a literatura não se constituíra numa forma de intervenção social; e a política tornara-se sinônimo de crise moral. Machado, então, orientou sua atenção para a crônica, onde assentaria suas reflexões sobre nossos rituais de convivência urbana. Intrigado com a configuração cultural que lhe escapava, impôs-se a ele buscar os traços psicossociais do brasileiro. Este artigo apresenta alguns resultados do esforço de Machado de Assis pela compreensão da brasilidade.

Palavras-chave: crônica; brasilidade; crítica cultural.

\section{Chronicle and Brazilianess: gleaning what is minute and hidden}

Abstract: Machado de Assis wrote the 246 chronicles of the series "A Semana" between 1892 and 1897. By then, he had already gone through many disappointments: Brazilian drama did not yield good results in the model of the French realistic theatre; literature had not become a form of social intervention; and politics had become synonymous with moral crisis. Machado then directed his attention to the chronicle, which would translate his thoughts about our urban life rituals. Intrigued by cultural settings that eluded him, he decided to seek the psychosocial features of the Brazilian people. This article 
presents some results of Machado de Assis's effort of to understand Brazilianness.

Keywords: chronicle; Brazilianness; cultural criticism.

Após silêncio de quase cinco anos, o cronista Machado de Assis reapareceu. Era o dia 2 de julho de 1883, data da primeira das 126 crônicas que compuseram a série "Balas de Estalo", encerrada em 22 de março de 1886. Foram publicadas na Gazeta de Notícias, órgão dirigido por seu amigo Ferreira de Araújo, onde também se divulgaram as crônicas machadianas das quatro séries seguintes: "A + B", entre 12 de setembro de 1886 e 24 de outubro de 1886, num total de sete; "Gazeta de Holanda", 49 crônicas em verso, de $1^{\circ}$ de novembro de 1886 a 24 de fevereiro de 1888; "Bons Dias!", série também composta de 49 crônicas, que abarcam o período de 5 de abril de 1888 a 29 de agosto de 1889; e, por fim, as 246 de "A Semana", publicadas entre 24 de abril de 1892 e 28 de fevereiro de 1897. Neste artigo, limitaremos nosso exame exclusivamente às reunidas sob a rubrica "A Semana", chamadas por Machado "conversações dominicais", 1 um conjunto de crônicas que é, indubitavelmente, o mais significativo entre todos os que escreveu.

Antes dessas cinco séries, Machado ainda não desenvolvera a "arte das transições", ${ }^{2}$ como ele próprio viria a nomear sua capacidade de transitar por múltiplos assuntos, sem necessariamente deter-se em algum; até então, os diversos temas eram tratados por ele, em cada crônica, sob a forma de fragmentos, encimados por números romanos. Além disso, ao longo dessas séries, Machado apurou o desembaraço irônico que lhe possibilitou gozar a dualidade e desconstruir as verdades absolutas, ao mesmo tempo em que foi definindo o que José de Alencar chamara, referindo-se ao folhetim, "volubilidade do estilo". Em relação a essas crônicas das décadas de 1880 e 1890, John

\footnotetext{
${ }^{1}$ ASSIS, Machado de. Obra completa em quatro volumes. 2.ed. v. 4. Rio de Janeiro: Nova Aguilar. p. 375 .

2 ASSIS, Machado de. Bons Dias!. Introdução e notas de John Gledson. 3.ed. Campinas: Editora da Unicamp, 2008. p. 128.
} 
Gledson declarou que elas "funcionaram, como noutras épocas os contos, como o meio mais apropriado para o que ele tinha a dizer". ${ }^{3}$

E o que Machado "tinha a dizer"? Desencantado com o teatro realista, que não se criara, e com a literatura, que não se constituíra numa forma direta de intervir politicamente, ele logo se distanciaria das ocorrências políticas e, agudizando seu "olhar de míope", orientaria seu texto para a experiência humana que, entre incorporar o fundamento externo e resistir a ele, acabaria por formar algo irremediavelmente brasileiro. A crônica machadiana desse período, portanto, carregaria uma crítica de feição cultural, no sentido de Machado ter-se comprometido com significações e valores da vida social brasileira. Essa busca por encontrar nossa personalidade coletiva nacional, segundo Alfredo Bosi, era uma das cogitações do tempo:

Essa primeira fonte para a caracterização geral do povo brasileiro conheceu sua fase áurea entre 1870 e 1920 aproximadamente, que é, não por acaso, o período de máxima expansão do imperialismo econômico inglês e do imperialismo cultural francês e alemão. ${ }^{4}$

Desse modo, em sua crônica madura é-nos oferecida uma assistemática teoria da cultura brasileira, que Machado construiu em conformidade com os múltiplos modos como a nacionalidade se oferecia e com a necessidade de afirmação coletiva naquele fim de século. A sintonia fina entre o escritor e a crônica, no entanto, ampliou o leque de dificuldades já comumente encontradas pelo estudioso de Machado de Assis no que concerne ao exercício hermenêutico, para o qual se faz necessária uma palavra acerca do narrador dessas crônicas. Vejamo-lo em cada um dos cinco conjuntos.

"Balas de Estalo" não era uma série exclusiva de Machado; nela, assinavam doze personagens-narradores que punham em confronto suas opiniões acerca de temas apresentados e desenvolvidos em outras seções da Gazeta de Notícias. Gilberto Pinheiro Passos define: "Assim trabalha nosso autor, jogando com paródias, alternando

\footnotetext{
${ }^{3}$ CULT - Revista Brasileira de Cultura. São Paulo: [s.n.], ano II, n.24, jul. 1999. p. 49.

${ }^{4}$ BOSI, Alfredo. Aventuras e desventuras de uma ideologia. In: LEITE, Dante Moreira. O caráter nacional: história de uma ideologia. 4. ed. São Paulo: Pioneira, 1983. p. XXII.
} 
perspectivas". ${ }^{5}$ Em "A + B", as personagens A e B dialogam sem notória interferência de João das Regras, pseudônimo de Machado de Assis. Poderíamos considerar, como tema central dessas sete crônicas, os desvios morais ligados a nosso modo de ser, fazer e agir nas relações com o dinheiro. Nesse sentido, o narrador de grau zero só o seria tecnicamente; leitores coevos de Machado teriam noção de quem fora João das Regras, ou, o que é mais provável, do que seu nome significava:

João das Regras era então apelido que cheirava a finanças e política. $\mathrm{E}$ $\mathrm{A}+\mathrm{B}$ ? A e $B$ são letras; se o assunto é finanças, letras de câmbio, por exemplo, ou, mais amplamente, papel que vale dinheiro, e dinheiro sem ouro como lastro. ${ }^{6}$

As crônicas rimadas de "Gazeta de Holanda" ampliam seu exame de nossas práticas culturais, tematizando a medicina popular, a polca, o entrudo, a capoeira... Essas crônicas eram assinadas por Malvólio. Assim como no caso de Lélio pseudônimo de "Balas de Estalo" - e João das Regras, não havia segredo da autoria, que era de conhecimento público, revelada pela revista A Semana, quando as crônicas estavam sendo publicadas. No caso da quarta série, "Bons Dias!", isso não aconteceu: a identificação de Machado de Assis como autor desses textos só ocorrerá nos anos 1950. A preservação desse anonimato tão longo permite deduzir o empenho de Machado em mantê-lo, certamente para poder expressar-se de modo mais desimpedido que em "Balas de Estalo", "A + B" e "Gazeta de Holanda", o que se explicaria pelas tensões políticas daquele tempo de crise, compreendido entre as vésperas da Abolição e as da República. Além da proteção do anonimato, havia a do pseudônimo (Policarpo), que, na série, ao contrário do que ocorrera nas três anteriores, não era grafado no fim da crônica. Isso, no entanto, não impediu Machado de servir-se dos sentidos propiciados por um

\footnotetext{
${ }^{5}$ PASSOS, Gilberto Pinheiro. Machado de Assis, nosso contemporâneo. In: ASSIS, Machado de. Balas de Estalo de Machado de Assis. Organização de Heloisa Helena Paiva de Luca. São Paulo: Annablume, 1998. p. 16.

${ }^{6}$ CHALHOUB, Sidney. A arte de alinhavar histórias - a série "A + B" de Machado de Assis. In: CHALHOUB, Sidney; NEVES, Margarida de Souza; PEREIRA, Leonardo Affonso de Miranda (Orgs.). História em cousas miúdas: capítulos de história social da crônica no Brasil. Campinas: Editora da Unicamp, 2005. p. 75.
} 
personagem-narrador, ainda que este, depois de apresentado na crônica inicial e nomeado na décima (de $1^{\circ}$ de junho de 1888), não mais se expusesse ao leitor.

É dessa autoproteção implicada no processo de escrita que Machado abre mão em "A Semana", a série de que trataremos. Aqui, não haverá o contraponto do autor com a máscara do pseudônimo, e, sem ela, vemo-lo mais francamente identificado com fatos e opiniões. Na série, alcançou o domínio de um estilo que Luiz Costa Lima nomeou "capoeira verbal", que consistiria em "desprezar uma lógica estritamente fundada em moldes escriturais, isto é, baseada em uma construção linearmente proposicional". ${ }^{7}$ Abrindo sua crônica de 19 de fevereiro de 1893, Machado incita o leitor a atentar para essa técnica:

É meu velho costume levantar-me cedo e ir ver as belas rosas, frescas murtas, e as borboletas que de todas as partes correm a amar no meu jardim. Tenho particular amor às borboletas. Acho nelas algo das minhas ideias, que vão com igual presteza, senão com a mesma graça. $^{8}$

Em "A Semana", Machado atinge o "humor definitivo",', essencial ferramenta para sua leitura do cultural e sua captação da identidade possível. John Gledson resume:

Essa espécie de reflexão sobre a natureza do caráter nacional brasileiro aparece numa forma tão desenvolvida somente nessa última série de crônicas, se não me engano, mas, mesmo não aparecendo com frequência, pode ser uma antecipação bastante surpreendente de ideias desenvolvidas mais tarde, no século XX. ${ }^{10}$

\footnotetext{
${ }^{7}$ LIMA, Luiz Costa. Machado: mestre de capoeira. In: SECCHIN, A.C.; ALMEIDA, J.M.G. de; SOUZA, R. M. (Orgs.). Machado de Assis: uma revisão. Rio de Janeiro: In-Fólio, 1998. p. 188.

${ }^{8}$ ASSIS, Machado de. A Semana: crônicas (1892-1893). Edição, introdução e notas de John Gledson. São Paulo: Hucitec, 1996. p. 199.

${ }^{9}$ CASTELlO, José Aderaldo. Realidade e ilusão em Machado de Assis. São Paulo: Companhia Editora Nacional, 1969. p. 57.

${ }^{10}$ GLEDSON, John. Por um novo Machado de Assis. São Paulo: Companhia das Letras, 2006. p. 203204.
} 
Para Machado, o processo de unificação nacional caminhava lado a lado com o fortalecimento de nossa identidade, esta forjada por manifestações culturais que, carregando mensagens, revelariam o brasileiro. Essa procura, no entanto, apresentava muitos obstáculos:

O que era ser brasileiro naquela sociedade cosmopolita e provinciana, moderna e antiquada, liberal e oligárquica - enfim, como situar-se, se não como cidadão pelo menos como indivíduo, naquela realidade cada vez mais fugidia, rarefeita, permeada de instabilidades sociais, com determinações racionais ou com base em esquemas sérios ou repertórios cognitivos tradicionais $?^{11}$

Ao fim do século XIX, ainda soariam razoáveis certas acentuações que remetiam a Herder e sua conceituação de caráter nacional. Em 1870, sob o êxito do Risorgimento, Massimo d'Azeglio comentaria: "Nós fizemos a Itália, agora temos que fazer italianos". ${ }^{12}$ Por todas as partes, ocorria essa busca pela peculiaridade de um povo e de uma nação. Para Machado, nossa identidade cultural ligava-se a "nosso atraso moderno", ${ }^{13}$ de cuja relação ressumariam nossos defeitos. Assim ele inicia sua crônica de 9 de julho de 1895:

Não estudei com Pangloss; não creio que tudo vá pelo melhor no melhor dos mundos possíveis. Por isso, quando acho que censurar na nossa terra, digo com os meus botões: há de haver males nas terras alheias, olhemos para a França, para a Itália, para a Rússia, para a Inglaterra, e acharemos defeitos iguais, e alguma vez maiores. ${ }^{14}$

Livre da carga de ironia, este extrato de 12 de abril de 1896 esclarece melhor seu argumento:

\footnotetext{
${ }^{11}$ SALIBA, Elias Thomé. A dimensão cômica da vida privada na República. In: SEVCENKO, Nicolau (Org.). História da vida privada no Brasil. v.3. São Paulo: Companhia das Letras, 1998. p. 297.

${ }^{12}$ Citado em: HOBSBAWM, Eric J. . Nações e nacionalismo desde 1780: programa, mito e realidade. Rio de Janeiro: Paz e Terra, 1990. p. 56.

${ }^{13}$ WAIZBORT, Leopoldo. Roberto Schwarz: entre forma literária e processo social. In: BOTELHO, André; SCHWARCZ, Lilia Moritz (Orgs.). Um enigma chamado Brasil: 29 intérpretes e um país. São Paulo: Companhia das Letras, 2009. p. 416.
}

${ }^{14}$ ASSIS, cit., nota 1, p. 1179. 
Nem sempre gosto de citar exemplos alheios. Também lá fora há defeitos e graves. Mas se os processos [no caso, jurídicos] fossem rápidos, como em algumas partes, mormente em pequenos crimes, creio que andaríamos muito melhor. ${ }^{15}$

Num mundo de emulação generalizada, a especificidade de cada povo residiria no seu modus faciendi. Entre nós, o campo jurídico, especificamente, muito serviu a Machado para identificar no brasileiro a falta do "sentimento da legalidade", ${ }^{16}$ que - se não é justificado por leis que desconsideram nossos costumes, o que ocorre tantas vezes - traz em si certo "gosto de não obedecer" a elas. ${ }^{17}$ Machado de Assis concordaria com as ideias de seu querido Émile Augier a respeito da consideração aos costumes. José Luís Jobim resume assim essas ideias do dramaturgo francês:

[...] há na estrutura das sociedades uma espinha dorsal tão importante para a economia geral quanto a espinha dorsal para o indivíduo: são os costumes. É por aí que as nações se mantêm, mais ainda que por seus códigos e constituições. A prova disto estaria no fato de que no dia seguinte das revoluções, durante o interregno das leis, os costumes se manteriam. ${ }^{18}$

Leiamos Machado:

A lei escrita pode ser obra de uma ilusão, de um capricho, de um momento de pressa, ou qualquer outra causa menos ponderável; o uso, por isso mesmo que tem o consenso diuturno de todos, exprime a alma universal dos homens e das coisas. ${ }^{19}$

\footnotetext{
${ }^{15}$ Idem, p. 1269.

${ }^{16}$ Idem, p. 1040.

${ }^{17}$ Idem, p. 1041.

${ }^{18}$ JOBIM, José Luís. Machado de Assis, membro do Conservatório Dramático Brasileiro e leitor do teatro francês. In: (Org.). A biblioteca de Machado de Assis. Rio de Janeiro: Academia Brasileira de Letras: Topbooks, 2001. p. 388-389.
}

${ }^{19}$ ASSIS, cit., nota 1, p. 1331. 
Para Machado, portanto, formuladas em desrespeito ao nosso "uso", muitas leis teriam por destino "o sono das coisas impressas e guardadas. Nem se pode dizer que são feitas para inglês ver". ${ }^{20}$ Assim nascidas, a infração a elas não autoriza a punição: "A pena é um espantalho". ${ }^{21}$

Permitimo-nos considerar sincera esta lamentação de Machado, em 8 de janeiro de 1893, após o cumprimento de uma lei municipal:

Mas vamos ao meu ofício, que é contar semanas. Contarei a que acaba e foi mui triste. A desolação da rua Primeiro de Março é um dos espetáculos mais sugestivos deste mundo. Já ali não há turcas, ao pé das caixas de bugigangas; os engraxadores de sapatos com as suas cadeiras de braços e o demais aparelho desapareceram; não há sombra de tabuleiro de quitanda, não há samburá de fruta. Nem ali nem alhures. Todos os passeios das calçadas estão despejados dela. Foi o prefeito municipal que mandou pôr toda essa gente fora do olho da rua, a pretexto de uma postura, que se não cumpria. ${ }^{22}$

Para além de seu "sentimento da pobreza", 23 a "desolação" da rua sugere um conjunto de matrizes culturais que lhe fugiam. As vozes dos vendedores de rua, elementos de identidade cultural, eram-lhe importantes como escritor, o que bem destacou Miécio Táti:

Essas e outras alegrias populares repontam, volta e meia, nas narrativas em que se fixam, ainda mesmo de forma incidente, os costumes da cidade, que aliava as brincadeiras próprias do lugar, suas festas e cantigas, às vindas de outros rincões. ${ }^{24}$

No entendimento de Machado, ao problema de nossas leis não servirem "o necessário para conjugar os interesses humanos, que são a base da harmonia social", ${ }^{25}$

\footnotetext{
${ }^{20}$ ASSIS, cit., nota 8, p. 178.

${ }^{21}$ Idem, p. 202.

${ }^{22}$ ASSIS, cit., nota 8, p. 177-178.

${ }^{23}$ SCHWARZ, Roberto. Mesa-redonda. In: BOSI, A.; GARBUGLIO, J.C.; CURVELO, M.; FACIOLI, V. (Orgs.). Machado de Assis. São Paulo: Ática, 1982. p. 325.

${ }^{24}$ TÁTI, Miécio. O mundo de Machado de Assis. Rio de Janeiro: Livraria São José, 1961. p. 180.

${ }^{25}$ ASSIS, cit., nota 1, p. 1332.
} 
somar-se-ia o de haver, entre nós, certo prazer em transgredi-las, reflexo de nossa falta de espírito público. A crônica de 21 de janeiro de 1894 ilustra essa ideia:

Maior que ele é o que eu disse a princípio, o gosto de não obedecer às leis. Aqui vai um exemplo. É mínimo; mas nem todas as flores são dálias e camélias; o pequeno miosótis também ocupa lugar ao sol. Ontem, ia andando um bonde, com pouca gente, três pessoas. A uma destas pareceu que o cocheiro estava fumando um cigarro; via-lhe ir a mão esquerda frequentes vezes à boca, de onde saía um fiozinho de fumo, que não chegava a envolver-lhe a cabeça, porque, com o andar do veículo, espalhava-se pelas pessoas que iam dentro deste.

- Os cocheiros podem fumar em serviço? - perguntou a pessoa ao condutor.

Fê-lo em voz baixa, tranquila, como quem quer saber, só por saber. $\mathrm{O}$ condutor, não menos serenamente, respondeu-lhe que não era permitido fumar.

- Então...?

- Mas ele só fuma aqui, no arrabalde; lá para o centro da cidade não fuma, não senhor.

Grande foi o espanto da pessoa, ouvindo essa tradução de Pascal, tão ajustada ao cigarro e ao bonde. Vérité en deçà, erreur au delà. Mas, pensando bem, este caso não é igual aos outros; aqui a singeleza da resposta mostra a sinceridade da interpretação. ${ }^{26}$

Nicolau Sevcenko oferece uma angulação interessante à questão, pondo-a no ambiente da ideologia do progresso e do individualismo carreado pela modernidade:

A convicção básica compartilhada por todos, porém, Machado incluído, é que pelo menos até se chegar à área central, ninguém, mesmo que incomodado, há de advertir o fumante ou cobrar a aplicação da lei. Até lá, o conjunto do veículo público é uma extensão do espaço privado do cocheiro e, sem dúvida, do condutor. A partir do centro, a história é outra. ${ }^{27}$

Embora sabendo que a identidade nacional que perseguia abrangesse o componente histórico, Machado impactou-se com as forças da ciência organizada e da inovação tecnológica, forjadas no ambiente de desenvolvimento do capitalismo liberal:

\footnotetext{
${ }^{26}$ Idem, p. 1041.

${ }^{27}$ SEVCENKO. Nicolau. A capital irradiante: técnica, ritmos e ritos do Rio. In: vida privada no Brasil. v. 3. São Paulo: Companhia das Letras, 1998. p. 526.
} (Org.). História da 
"Não há dúvida que os relógios, depois da morte de López [Solano López, morto em 1870], andam muito mais depressa". ${ }^{28}$ Para ele, perdia-se o que chamou "sensação do tempo", ${ }^{29}$ por ação da modernidade mecanicista - eram "tempos pecuniários", ${ }^{30}$ próprios de um século "utilitário e prático". ${ }^{31}$ Machado tinha a percepção de que esse conjunto de forças conduziria, genericamente, à afirmação do individualismo; na sociedade brasileira, porém, esse individualismo se teria agudizado a ponto de, para além dessa orientação histórica natural, revelar uma característica de nosso grupo. Na crônica de 7 de maio de 1893, ele tematiza a possibilidade de abrir-se exceção a algum "estranho", com o fim de este assistir a uma sessão da Câmara. O sarcasmo reforça a ideia de que ele está lidando com o modelo qualitativo brasileiro:

Quando a exceção recai em Pedro ou Paulo, eu lanço os olhos a Sancho e a Martinho, e a todos os nomes do calendário, e posso medir a injustiça daquele único ponto no meio da extensão vastíssima dos homens. Quando, porém, a escolha recai em mim, recolho-me em mim mesmo por um movimento involuntário; o mundo exterior desaparece, fico com a minha individualidade, com o meu direito anterior e superior. Todo eu sou regra; não acho, não posso achar injustiça na escolha. Comigo está o universo. ${ }^{32}$

É seguro que ele refletia sobre o Brasil; confirmam isso duas crônicas, uma anterior, outra posterior a essa. Na de 29 de maio de 1892, dissera: "Nós fazemos tudo por vontade, por escolha, por gosto; e, de duas uma: ou isto é a perfeição final do homem, ou não passa das primeiras verduras". ${ }^{33} \mathrm{E}$ na posterior, de 27 de agosto de 1893, chegava a propor um "estudo" - que, de certo modo, já empreendia:

Talvez não nos falte o bacilo do júri, mas o da reunião, o da assembleia, o de tudo que exige presença obrigada. A razão de estar a rua do Ouvidor sempre cheia é poder cada um ir-se embora; ficam

\footnotetext{
${ }^{28}$ ASSIS, cit., nota 1, p. 1058.

${ }^{29}$ Idem, p. 1119.

${ }^{30}$ Idem, p. 1162.

${ }^{31}$ ASSIS, cit., nota 8, p. 233.

${ }^{32}$ Idem, p. 237.

${ }^{33}$ Idem, p. 67.
} 
todos. Há nada melhor que uma ópera que entra pelo ouvido, enquanto os olhos, pegados ao binóculo, percorrem a sala? São pontos que merecem estudo particular. ${ }^{34}$

Sob a máscara do arrivismo burguês ou da apatia popular, o individualismo do brasileiro fazia-o ligado a outro apenas na curiosidade:

Até agora estes desastres [de bonde] seguiam invariavelmente os mesmos trâmites. A vítima, bicho ou gente, morta ou ferida, caía na rua. A multidão aglomerava-se em redor dela, olhando calada como é seu pacífico costume. ${ }^{35}$

Segundo Alberto Sales, "o brasileiro era muito sociável, mas pouco solidário". ${ }^{36}$ Essa ausência de senso de coletividade casava com o cumprimento de certas tendências: "os açougueiros, sem estudos acadêmicos, sabem muito bem que um quilo pesa setecentos e cinquenta gramas. Isto apenas mostra vocação. Há vocações sem estudos". ${ }^{37}$ A degradação moral a que Machado assistia era tão profunda que lhe impunha, algumas vezes, renunciar à ironia; após a divulgação de que (também) o café estava falsificado, ele pergunta e responde: "Como faremos eleições puras, se falsificamos o café, que nos sobra? Espírito da fraude, talento da embaçadela, vocação da mentira, força é engolir-vos também de mistura com a honestidade de tabuleta". ${ }^{38}$

Machado trabalhava com dados empiricamente observáveis, emersos da vida cotidiana. Pontualmente, isso o fez recuar a ajuizamentos que se naturalizaram por força da repetição. Não sem crueldade, ele diz, na crônica de 3 de novembro de 1895:

Se alguma coisa merecem os meus pecados, peço a Deus a vida precisa para nesses dias futuros incorporar uma companhia, receber vinte por cento das entradas, levantar um empréstimo para fazer a

\footnotetext{
${ }^{34}$ Idem, p. 291.

${ }^{35}$ ASSIS, cit., nota 1, p. 1269.

${ }^{36}$ Citado em: CARVALHO, José Murilo de. Os bestializados: o Rio de Janeiro e a República que não foi. São Paulo: Companhia das Letras, 1987. p. 150.

${ }^{37}$ ASSIS, cit., nota 1, p. 1070.

${ }^{38}$ Idem, nota 8, p. 161.
} 
obra, não fazer a obra, fazer as malas e fazer a viagem do céu com escala pela Europa. ${ }^{39}$

Quase um ano antes, por ocasião do suicídio de um homem de negócios, ocorrido supostamente por ele "não poder pagar aos credores", Machado apontou o ineditismo daquele desfecho: "Era natural não admitir que, em tal situação, um empresário prefira a bala ao paquete". ${ }^{40}$ Aqui, por exemplo, Machado estaria encorpando um estereótipo fixado havia tempos, como se comprova na já então remota História do Brasil: 1500 - 1627, de Frei Vicente do Salvador, morto na década de 1630, para quem "nem um homem nesta terra é repúblico, nem zela ou trata do bem comum, senão cada um do bem particular". ${ }^{41}$ E ilustrava:

Pois o que é fontes, pontes, caminhos e outras coisas públicas é uma piedade, porque, atendo-se uns aos outros, nenhum as faz, ainda que bebam água suja e se molhem ao passar dos rios ou se orvalhem pelos caminhos, e tudo isto vem de não tratarem do que há cá de ficar, senão do que hão de levar para o reino. ${ }^{42}$

"Pobre Brasil!", escreve Machado em 1893, na crônica da semana de Finados. $^{43}$

José Murilo de Carvalho considera o Encilhamento responsável por modificações em nossos padrões de moral e de honestidade:

Poderíamos dizer que se deu uma vitória do espírito do capitalismo desacompanhado da ética protestante. Desabrochou o espírito aquisitivo solto de qualquer peia de valores éticos, ou mesmo de cálculo racional que garantisse a sustentação do lucro a médio prazo. ${ }^{44}$

\footnotetext{
${ }^{39}$ Idem, nota 1 , p. 1233.

${ }^{40}$ Idem, p. 1100.

${ }^{41}$ SALVADOR, Frei Vicente do. História do Brasil: 1500 - 1627. Belo Horizonte: Itatiaia; São Paulo: Edusp, 1982. p. 58.

${ }^{42}$ Idem, p. 58.

${ }^{43}$ ASSIS, cit., nota 8, p. 326.

${ }^{44}$ CARVALHO, José Murilo de. Os bestializados: o Rio de Janeiro e a República que não foi, cit., nota 36, p. 26-27.
} 
Interessa-nos mais de perto, aqui, o termo "desabrochou", utilizado pelo historiador. Esse verbo faz supor que, antes do Encilhamento, haveria potencialmente no brasileiro, de modo "semiclandestino", uma tendência - que Machado chamou, sarcasticamente, de "vocação" - que se consolidaria pelo desencadeamento da conjuntura político-financeira. Seria, pois, dentro de um ambiente desolador, um traço nacional, como pode-se ler na crônica de 23 de fevereiro de 1896:

Dickens, em Oliver Twist, põe uma escola composta de meninos apanhados aqui e ali, para aprender o ofício de gatuno. Os diplomados saem depois do almoço e voltam à tarde, com o produto do ofício. Os novatos ficam aprendendo com o fundador do estabelecimento. Mas haverá aqui necessidade de escola? As vocações não são naturais e vivas e a arte não vem com a prática? ${ }^{45}$

À época, embora já descrente da política, Machado parecia crer, ainda que pontualmente, que as eleições pudessem alterar o quadro de nossa realidade social: "Mas não me faças ir adiante, leitor amado. Adeus, vai votar. Escolhe a tua intendência e ficarás com o direito de gritar contra ela". ${ }^{46}$ Quase um ano depois dessa incitação, porém, na crônica de 15 de outubro de 1893, ele reagiria a si mesmo: "O eleitor é, em grande parte, distraído, indolente e um pouco ignorante". ${ }^{47}$ À luz de nossa argumentação, é esta segunda fala que representa a real convicção de Machado, naquela última década do século. A escolha dessa fala, a propósito, bem ilustraria a lição oferecida por Daniela Mantarro Callipo acerca do modo de ler a ironia de Machado: "Ele pode ser um fingidor, como o poeta, e fingir que é verdade o que de fato é". ${ }^{4}$

O cronista Machado de Assis lia o cotidiano do Rio de Janeiro, metonímia do Brasil, como um conjunto de textos onde havia algo de irredutível, íntimo, que atravessava impulsos e atos. E Machado leu e releu a venalidade eleitoral: "Mas, que

\footnotetext{
${ }^{45}$ ASSIS, cit., nota 1, p. 1255.

${ }^{46}$ Idem, nota 8, p. 144.

${ }^{47}$ Idem, p. 315.

${ }^{48}$ CALLIPO, Daniela Mantarro. O perfil singular da crônica machadiana. Jornal UNESP, São Paulo, $\mathrm{n}$. 232, abr. 2008. Disponível em: <http://www.unesp.br/aci/jornal/232/suplec.php>. Acesso em: $10 \mathrm{de}$ dezembro de 2010.
} 
remédio dou então para fazer eleições puras? Nenhum; não entendo de política". ${ }^{49}$ Dissera isso em 8 de dezembro de 1895; em crônica anterior, porém, quando a ironia foi mais ferina e menos desencantada, ele propusera algo:

Vindo à minha ideia, acho que a reforma eleitoral, para ser útil e fecunda, há de consistir em dar às eleições um aspecto acentuadamente esportivo. Em vez de esperar que o desejo de escolher representantes leve o eleitor às urnas, devemos suprir a ausência ou a frouxidão desse impulso pela atração das próprias urnas eleitorais. A lei deve ordenar que os candidatos sejam objeto de apostas, ou com os próprios nomes, ou (para ajudar a inércia dos espíritos) com outros nomes convencionais, um por pessoa, e curto. Não entro no modo prático da ideia; cabe ao legislador achá-lo e decretá-lo. A abstenção ficará vencida [...]. ${ }^{50}$

Conhecem-se as posições de Machado acerca do jogo. Na sua crítica da cultura brasileira, o jogo era um longo texto, lido sob o ângulo das loterias - simbolizadas sobretudo pelo jogo do bicho -, ou sob o da atividade física em si.

Machado tinha aversão por nossa "paixão do azar", 51 que ele associava à ideia de que, no imaginário nacional, a relação entre enriquecimento e trabalho não era necessária nem suficiente. Em boa medida, já estaria em Machado a pergunta formulada, quase seis décadas depois, por Viana Moog: "Não será o brasileiríssimo jogo do bicho autêntica expressão do terror subconsciente, como da aspiração muito brasileira de riqueza rápida?". ${ }^{52} \mathrm{Na}$ crônica de 12 de julho de 1896, ao comentar a campanha contra o jogo do bicho, empreendida pela imprensa e pela polícia, ele machadianamente expõe sua convicção de nosso pendor ao azar:

A minha dúvida única é se o bicho morto não ressuscitará com diversa forma. Agora mesmo nem tudo são bichos; há prêmio de bebidas, distribuição de gravuras e outras convenções de azar. Convém ter em vista que os jogos são muitos. A loteria, um dos mais velhos, que tem desmoralizado a sociedade, serve com seus números

\footnotetext{
${ }^{49}$ ASSIS, cit., nota 1, p. 1234.

${ }^{50}$ Idem, p. 1087.

${ }^{51}$ Idem, p. 1297.

${ }^{52}$ MOOG, Viana. Bandeirantes e pioneiros. São Paulo: Globo, 1957. p. 337.
} 
às várias especulações; mas não é a única culpada desta perversão de costumes. Única não pode ser; ela corrompe, ela deve ser extirpada, como outras instituições de dar fortuna; mas não esqueçamos que ela é também efeito. Contaram-me que por ocasião do Encilhamento essa enorme bicharia, em que todos os carneiros perderam - ocorria um fato assaz característico. Sabe-se que na rua da Alfândega o ajuntamento era grande e o tumulto, frequente. Alguma vez foi preciso empregar força para aquietar os ânimos e dar passagem a outra gente. Sucedia então que, saindo a correr dois praças de cavalaria através da multidão, eram os próprios animais objeto de apostas, dizendo uns que o primeiro cavalo que chegava à esquina era o de cá, e outros que era o de lá, e os que acertavam recebiam um ou dois contos de réis. ${ }^{53}$

O Encilhamento - termo subtraído do universo da corrida de cavalos e que remete ao momento em que se fixam as selas, pouco antes da largada, quando então sobe a excitação das apostas - ainda estava fresco e doía na memória de Machado. Entre o decreto de 17 de janeiro de 1890 e sua revogação em 23 de novembro de 1891, essa intensa especulação financeira rendeu a Machado, talvez, suas páginas mais desencantadas e mais ríspidas. Anos depois, o Encilhamento ainda repercutiria, na forma de protestos e falências. Ter-se-iam unido, ali, nosso pendor ao azar e nosso pendor à riqueza sem o custo do trabalho. Na crônica de 28 de maio de 1893, Machado relembra: "Esta cidade [...], durante l'année terrible (1890 - 1891), apostou sobre todas as coisas do céu e da terra". ${ }^{54}$ Apostou e, para ele, perdeu. De acordo com José Murilo de Carvalho, a "confiança na sorte, no enriquecimento sem esforço em contraposição ao ganho da vida pelo trabalho honesto parece ter sido incentivada pelo surgimento do novo regime". 55 Da mesma forma que, em página anterior, analisamos o verbo "desabrochou", usado por Carvalho, aqui destacamos a locução "ter sido incentivada", também ela indicativa de um "pendor", segundo Machado, detonado por certo panorama particular. Se não era um traço imutável do brasileiro, porque afinal sua projeção dependia de certas condições, servia-lhe como inquirição de nossa identidade.

\footnotetext{
${ }^{53}$ ASSIS, cit., nota 1, p.1297.

${ }^{54}$ Idem, nota 8, p. 246.

${ }^{55}$ CARVALHO, José Murilo de. Os bestializados: o Rio de Janeiro e a República que não foi. cit., nota 36, p. 28.
} 
Também o jogo como atividade física, porém, mereceu-lhe a atenção. Machado o via incompatível com a atividade intelectual, desposando a visão da época, resgatada por João do Rio em crônica de 1917:

Fazer sport há vinte anos ainda era para o Rio uma extravagância. As mães punham as mãos na cabeça quando um dos meninos arranjava um haltere. Estava perdido. Rapaz sem pince-nez, sem discutir literatura dos outros, sem cursar as academias - era homem estragado. ${ }^{56}$

A imagem desse rapaz letrado, no entanto, ia-se perdendo. Em 4 de novembro de 1894, ao comentar o prefácio de Lúcio de Mendonça a Versos, Machado diz que aquela página também servia "para convidar essa multidão de distraídos a deter-se um pouco a ler". ${ }^{57}$ Nos braços da modernidade, a emergente indústria cultural, que se confundiria com a indústria do entretenimento, seria o lugar do esporte. A ampla desafeição pela leitura incomodava Machado, tanto quanto o entusiasmo pelas competições esportivas, popularizadas rapidamente. Para ele, nossa sociedade funcionava no raso das ideias, no universo de uma "cultura preponderantemente auditiva", como Luiz Costa Lima viria a nomear a "cultura que se transmite sem cadeias demonstrativas". ${ }^{58}$ Na crônica de 17 de novembro de 1895, Machado afirmaria: "O povo ama as coisas que o alegram", ${ }^{59}$ e essas coisas traziam a alegria dos sentidos, renunciavam à complexidade intelectual, por exemplo, da leitura. Amaríamos, então, o esporte, na linha em que amávamos a dança. "Que se dance, é a nossa alma, a nossa paixão social e política", prescreveria ele em 24 de novembro de 1895, maneira machadiana de dizer o que diria Sílvio Romero doze anos depois: "É impossível falar a homens que dançam". 60

\footnotetext{
56 RIO, João do. Hora do football. In: RAMOS, Ricardo (Org.). A palavra é... futebol. São Paulo: Scipione, 1993. p. 18.

${ }^{57}$ ASSIS, cit., nota 1, p. 1117.

58 LIMA, Luiz Costa. Dispersa demanda: ensaios sobre literatura e teoria. Rio de Janeiro: Francisco Alves, 1981. p. 17.

${ }^{59}$ ASSIS, cit., nota 1, p. 1227.

${ }^{60}$ Citado em SALIBA, Elias Thomé. A dimensão cômica da vida privada na República. In: SEVCENKO, Nicolau (Org.). História da vida privada no Brasil. v.3, cit., nota 11, p. 296.
} 
Machado de Assis parecia seguro ao definir povos diferentes do nosso. Em relação aos norte-americanos, recorre à contiguidade: "Nunca amei o espírito prático daquela nação"; ${ }^{61}$ para caracterizar os ingleses, perfaz um sinuoso caminho, traçado na crônica de 14 de maio de 1893:

Um velho autor da nossa língua - creio que João de Barros; não posso ir verificá-lo agora; ponhamos João de Barros... Este velho autor fala de um provérbio que dizia: "os italianos governam-se pelo passado, os espanhóis, pelo presente e os franceses, pelo que há de vir." E em seguida dava "uma repreensão de pena à nossa Espanha", considerando que Espanha é toda a península, e só Castela é Castela. A nossa gente, que dali veio, tem de receber a mesma repreensão de pena; governa-se pelo presente, tem o porvir em pouco e o passado em nada ou quase nada. Eu creio que os ingleses resumem as outras três nações. ${ }^{62}$

Para chegar aos ingleses, Machado passa pelos brasileiros, estabelecendo que nós mantemos com eles um déficit na consideração às tradições e na capacidade empreendedora; além disso, faz-nos pagar o preço da filiação.

Se Machado não teme operar abusivamente na definição do caráter de outros povos, no caso brasileiro ele age com extremo cuidado, esforçando-se por compreender as contradições do povo que forma a incerta comunidade imaginada conhecida por Brasil. Para enfrentar tais contradições, ele desenvolveu a estratégia discursiva de buscar incessantemente a diversidade de ângulos. Trabalhando com contrapontos, pôde penetrar nossos quadros culturais e nossa identidade problemática, conjugando a fluidez do discurso com a fluidez do objeto. Diz-nos José Murilo de Carvalho: "A identidade [...] é algo que se constrói ao longo do tempo e se manifesta de muitas maneiras, nem sempre coerentes". ${ }^{63}$ Machado, acrescente-se, soube favorecer-se do ambiente da crônica, também ele fluido, que lhe permitiu explorar à perfeição sua ironia multiplicadora de sentidos. Dizendo-se um "eterno divergente", ${ }^{64}$ esteve à vontade para

\footnotetext{
${ }^{61}$ ASSIS, cit., nota 1, p. 1303.

${ }^{62}$ Idem, nota 8, p. 240.

${ }^{63}$ CARVALHO, José Murilo de (Org.). Nação e cidadania no império: novos horizontes. Rio de Janeiro: Civilização Brasileira, 2007. p. 8.
}

${ }^{64}$ ASSIS, cit., nota 8, p. 162. 
pôr a andar a inteligência do leitor, obrigando-o a novas perspectivas, por meio de piparotes como este, da crônica de 25 de setembro de 1892: "concordo que o meu vezo de falar por meias palavras pode muito bem dar um sentido ao que o tem diverso". ${ }^{65}$ Articulada a essas flutuações, haveria, no próprio cronista, uma contradição íntima e complexa, fixada agudamente por Roberto Schwarz no ensaio "Martinha vs. Lucrecia", escrito acerca da crônica machadiana de 5 de agosto de 1894. Segundo Schwarz, esse mal-estar nasce do momento em que o cronista, intelectual europeizado, enfrenta a questão de que "a falta de reconhecimento em que vivem [Martinha e os outros compatriotas brasileiros pobres] não deixa de lhe dizer respeito". ${ }^{66}$ Nesse ponto, desvela-se o nacionalismo de Machado, que a análise de sua cronística, sobretudo de "A Semana", permite-nos - sem "pé-atrás" - afirmar. Schwarz diria:

Volta e meia, a despeito da couraça retórica, o escritor parece reconhecer como suas a gente e as localidades da ex-colônia, agora o Brasil. Implícita, há também a recíproca, segundo a qual essa gente e essas localidades poderiam contar com ele nalgum grau. ${ }^{67}$

No estudo que fez da crônica de Machado publicada em 9 de outubro de 1892, Alfredo Bosi explicaria o que denominou "estilística do distanciamento", uma alteração na maneira machadiana de expressão, devida a seu desencanto pela cena política e social: "uma linguagem de distanciamento pela qual o sujeito se põe e se declara existencialmente alheio à conjuntura que tinha virado manchete em todos os jornais do país". ${ }^{68}$ Nos anos de "A Semana", no entanto, houve muitos momentos em que ele temeu pelo processo de consolidação nacional. Sob esse receio, empreendeu esforços no sentido de alcançar a unidade simbólica de uma "pátria cultural", indissociável da identidade que se construía naqueles tempos difíceis. Nesse sentido, pode-se dizer que assinaria estas palavras de José Murilo de Carvalho:

\footnotetext{
${ }^{65}$ Idem, p. 125.

66 SCHWARZ, Roberto. Martinha vs. Lucrecia. In: ANTUNES, Benedito; MOTTA, Sérgio Vicente (Orgs.). Machado de Assis e a crítica internacional. São Paulo: Editora da Unesp, 2009. p. 24.

${ }^{67}$ Idem, p. 22.

${ }^{68}$ BOSI, Alfredo. Brás Cubas em três versões: estudos machadianos. São Paulo: Companhia das Letras, 2006. p. 62.
} 
Não há nação sem identidade nacional. Mas se as nações são, como dizia Renan, plebiscitos cotidianos, assim também as identidades são construções permanentes, nunca completadas, em que se envolvem elites, povo, governos, intelectuais, artistas. ${ }^{69}$

Correndo os riscos da ilusão e da ingenuidade, riscos altíssimos para alguém como Machado de Assis, empenhou-se na compreensão de quem éramos nós, inscrevendo-se entre os pioneiros do que seria uma tradição continuamente retomada. Diz-nos Ludwig Lauerhass, Jr.:

Tanto os pensadores do século XIX como os cientistas sociais e críticos culturais de hoje exploraram e voltaram a explorar a questão da especificidade brasileira - a experiência nacional, a brasilidade, $o$ caráter ou a realidade nacional, a memória coletiva e o "problema nacional" - contra um pano de fundo social, político, econômico e intelectual em constante transformação e à luz de novas teorias e metodologias acadêmicas. ${ }^{70}$

Para capturar a imagem em movimento que documentaria os brasileiros e o Brasil, Machado teve de superar dois obstáculos íntimos: sua reserva em relação às formas culturais mais populares e sua inadaptação ao processo de massificação cultural. Para alguém que se formara num ambiente que hierarquizava os produtos culturais, foilhe custoso aceitar as implicações promovidas pela intervenção popular; essas reticências, no entanto, sucumbiram ante a desconcertante atração que experimentou pela vitalidade dessas práticas populares, forças de que o plano erudito parecia esvaziado. À época, acrescente-se, a aglomeração urbana carioca gerava um público sempre mais diversificado; para atender a ele, acudiam os primeiros movimentos da indústria cultural, em que arte, tecnologia e publicidade consorciavam-se. A emergente cultura de massa intrigava Machado, e foi tal inquietação uma das razões que lhe suscitaram a ambição de compreender o povo com a qual estava implicada. Buscando

${ }^{69}$ CARVALHO, José Murilo de (Org.). Nação e cidadania no império: novos horizontes, cit., nota 63, p. 9.

${ }^{70}$ LAUERHASS, JR., Ludwig. Um cânone de quatro partes para a análise da identidade nacional brasileira. In: ; NAVA, Carmen (Orgs.). Brasil: uma identidade em construção. São Paulo: Ática, 2007. p. 11. 
em nossa sensibilidade coletiva índices sociais e culturais passíveis de simbolização, Machado encontrou traços comuns a essas pessoas interligadas, na dinâmica da cultura, por suas formas de pensar, comportar-se e comunicar-se. Assim, ao mesmo tempo em que produzia uma particular teoria cultural brasileira, num percurso cheio de conflitos e de lacunas, ia alcançando uma abstração: o brasileiro.

Para Machado, faltava-nos espírito público, de que derivariam nossa venalidade eleitoral e nosso desapreço pelas leis; tínhamos desvios morais no modo de ser, fazer e agir com o dinheiro; éramos individualistas, apáticos e imaturos psicologicamente, o que se verificaria, por exemplo, por nosso gosto pela ostentação e por nosso culto da aparência. Escrevendo numa época em que eram correntes formulações mais naturalizadas sobre caráter nacional, Machado não pôde fugir - pela ótica atual - a algum estereótipo de grupo. À distância de 120, 130 anos, parece faltar a Machado de Assis a percepção da ideologia que subjaz os traços psicossociais que encontrou no brasileiro, traços, porventura, plantados, cultivados e colhidos por colonizadores e, posteriormente, por proprietários, a respeito de colonizados, escravos e dependentes; mas isso seria pedir, não apenas de Machado, mas de todo aquele fim de século, o que o fim de século não poderia dar. Sua crônica madura, portanto, deve ser tomada como contribuição ao leque de discursos fundadores da identidade brasileira, e Machado deve ser incluído entre aqueles que formavam e formariam a tradição de pensar a brasilidade, a qual, no oitocentos, remete a José Bonifácio de Andrada e Silva, passa por seus contemporâneos Capistrano de Abreu e Sílvio Romero, cruza o século $\mathrm{XX}$ e ainda se mostra sedutora nos dias de hoje.

Referências:

ASSIS, Machado de. A Semana: crônicas (1892-1893). Edição, introdução e notas de John Gledson. São Paulo: Hucitec, 1996.

Bons Dias!. Introdução e notas de John Gledson. 3.ed. Campinas: Editora da Unicamp, 2008. 
. Obra completa em quatro volumes. 2.ed. v. 4. Rio de Janeiro: Nova Aguilar.

BOSI, Alfredo. Aventuras e desventuras de uma ideologia. In: LEITE, Dante Moreira. O caráter nacional: história de uma ideologia. 4. ed. São Paulo: Pioneira, 1983.

Brás Cubas em três versões: estudos machadianos. São Paulo: Companhia das Letras, 2006.

CALLIPO, Daniela Mantarro. O perfil singular da crônica machadiana. Jornal UNESP, São Paulo, n. 232, abr. 2008. Disponível em: <http://www.unesp.br/aci/jornal/232/suplec.php>. Acesso em: 10 de dezembro de 2010.

CARVALHO, José Murilo de (Org.). Nação e cidadania no império: novos horizontes. Rio de Janeiro: Civilização Brasileira, 2007.

Os bestializados: o Rio de Janeiro e a República que não foi. São Paulo: Companhia das Letras, 1987.

CASTELlO, José Aderaldo. Realidade e ilusão em Machado de Assis. São Paulo: Companhia Editora Nacional, 1969.

CHALHOUB, Sidney. A arte de alinhavar histórias - a série "A + B" de Machado de Assis. In: CHALHOUB, Sidney; NEVES, Margarida de Souza; PEREIRA, Leonardo Affonso de Miranda (Orgs.). História em cousas miúdas: capítulos de história social da crônica no Brasil. Campinas: Editora da Unicamp, 2005.

CULT - Revista Brasileira de Cultura. São Paulo: [s.n.], ano II, n.24, jul. 1999.

GLEDSON, John. Por um novo Machado de Assis. São Paulo: Companhia das Letras, 2006.

HOBSBAWM, Eric J. . Nações e nacionalismo desde 1780: programa, mito e realidade. Rio de Janeiro: Paz e Terra, 1990.

JOBIM, José Luís. Machado de Assis, membro do Conservatório Dramático Brasileiro e leitor do teatro francês. In: (Org.). A biblioteca de Machado de Assis. Rio de Janeiro: Academia Brasileira de Letras: Topbooks, 2001.

LAUERHASS, JR., Ludwig. Um cânone de quatro partes para a análise da identidade nacional brasileira. In: ; NAVA, Carmen (Orgs.). Brasil: uma identidade em construção. São Paulo: Ática, 2007.

LIMA, Luiz Costa. Dispersa demanda: ensaios sobre literatura e teoria. Rio de Janeiro: Francisco Alves, 1981.

Machado: mestre de capoeira. In: SECCHIN, A.C.; ALMEIDA, J.M.G. de; SOUZA, R. M. (Orgs.). Machado de Assis: uma revisão. Rio de Janeiro: In-Fólio, 1998. 
MOOG, Viana. Bandeirantes e pioneiros. São Paulo: Globo, 1957.

PASSOS, Gilberto Pinheiro. Machado de Assis, nosso contemporâneo. In: ASSIS, Machado de. Balas de Estalo de Machado de Assis. Organização de Heloisa Helena Paiva de Luca. São Paulo: Annablume, 1998.

RIO, João do. Hora do football. In: RAMOS, Ricardo (Org.). A palavra é... futebol. São Paulo: Scipione, 1993.

SALIBA, Elias Thomé. A dimensão cômica da vida privada na República. In: SEVCENKO, Nicolau (Org.). História da vida privada no Brasil. v.3. São Paulo: Companhia das Letras, 1998.

SALVADOR, Frei Vicente do. História do Brasil: 1500 - 1627. Belo Horizonte: Itatiaia; São Paulo: Edusp, 1982.

SCHWARZ, Roberto. Martinha vs. Lucrecia. In: ANTUNES, Benedito; MOTTA, Sérgio Vicente (Orgs.). Machado de Assis e a crítica internacional. São Paulo: Editora da Unesp, 2009.

Mesa-redonda. In: BOSI, A.; GARBUGLIO, J.C.; CURVELO, M.; FACIOLI, V. (Orgs.). Machado de Assis. São Paulo: Ática, 1982.

SEVCENKO. Nicolau. A capital irradiante: técnica, ritmos e ritos do Rio. In: (Org.). História da vida privada no Brasil. v. 3. São Paulo: Companhia das Letras, 1998.

TÁTI, Miécio. O mundo de Machado de Assis. Rio de Janeiro: Livraria São José, 1961.

WAIZBORT, Leopoldo. Roberto Schwarz: entre forma literária e processo social. In: BOTELHO, André; SCHWARCZ, Lilia Moritz (Orgs.). Um enigma chamado Brasil: 29 intérpretes e um país. São Paulo: Companhia das Letras, 2009.

Eduardo Luz, doutor em Literatura Comparada pela Universidade do Estado do Rio de Janeiro, é professor do Curso de Letras da Universidade Federal do Ceará. Tem seis livros publicados: quatro romances (Quer vele, quer sonhe; Sangues; Lembrar, lembrava; e Depois-depois das guerras) e duas obras teóricas (Manual de bruxaria introdução à obra crítica de Machado de Assis; e Como fumaça erguidos). E-mail: <eduardocrluz@gmail.com> 
Artigo: 09/02/2012

Aprovado: 15/05/2012 